\title{
STATE FISCAL SERVICE AS A BODY OF PUBLIC ADMINISTRATION
}

Marushak A. V.

\section{INTRODUCTION}

Public administration is a way of public policy implementation is carried out in many areas. It helps to focus on planning, organizing, directing, coordinating, and controlling a significant number of administrative objects. In this context, it is predictable and logical that public administration entities extend their activities to the financial field. This allows for increased state revenues, equitable distribution of public funds and resources. Public administration in the financial field involves all activities related to finance and taxation. We are also referring to accounting and audit, financial distribution surveillance, debt and investment management, collection, and disbursement. That is, the purpose of public administration is to execute measures and financial transactions that will allow uninterrupted and efficient use of budget funds. Public administration in financial sectors is carried out through a system of state bodies- the subjects of public administration. These include the State Treasury Service of Ukraine, the Ministry of Finance of Ukraine, the State Tax Service of Ukraine, the State Financial Monitoring Service of Ukraine, the State Fiscal Service, etc.

The State Fiscal Service of Ukraine plays a significant role in state policy development in several areas. In particular, this applies to public administration too. The study of the spheres of its activity, tasks, functions, and powers of the State Fiscal Service of Ukraine is quite relevant, as in recent years Ukraine strives to keep up with changes in the world community and implements reforms in its own power and legal spheres. Thanks to them, the State Fiscal Service of Ukraine was established.

\section{Scientific and legal characteristics of the State Fiscal Service of Ukraine}

The State Fiscal Service of Ukraine (SFS) is a central executive body whose actions are directed and coordinated by the Cabinet of Ministers of Ukraine through the Minister of Finance, and the one which introduces state tax policy, state policy across state customs, state policy on the administration of a single contribution to mandatory state social insurance, 
state policy in combating offenses during application of tax and customs legislation, as well as legislation of unified social tax ${ }^{1}$.

The State Fiscal Service was established in 2014. On May 21, 2014, the Cabinet of Ministers of Ukraine adopted Resolution № 160 to establish the State Fiscal Service as a central executive body whose activities ${ }^{2}$ are managed by the Cabinet of Ministers of Ukraine, reorganizing the Ministry of Revenue and Duties by transformation.

The formation of the SFS was the result of large-scale reforms that affected various areas. The introduction of new taxation reforms requires new ways of interaction between the subjects of tax relations, reformation of the tax system, and the fiscal service in general, to change the business and regulatory authorities relations ${ }^{3}$.

There is still no ultimate consensus among scientists and practitioners on the expediency of the SFS formation. Some believe that this clearly has a positive effect on the customs and tax spheres, whereas others believe that the newly formed SFS is nothing more than a liquidated Ministry of Finance and Duties. Thus conclude the irrationality of such a reform.

It is worth noting that the regularity of this change was due to the inconsistency of the powers of the former Ministry of Revenue and Duties, which were more typical of inspections, services and agencies, the status of the Ministry ${ }^{4}$.

This assumption seems reasonable. Analyzing the provisions of the Law of Ukraine «On Central Executive Bodies», which regulates the activities of ministries and other central executive bodies, we conclude that the content of the powers exercised by the State Fiscal Service is indeed more specific and characterizes that central body of executive power as a service. The confirmation of this conclusion is indicated by Article 17 of the above law: if most of the functions of the central executive body are to

${ }^{1}$ Про державну фіскальну службу: Постанова Кабінету Міністрів України; Положення від 21.05.2014 № 236

${ }^{2}$ Гнатовська А.І. Правові засади створення державної фіскальної служби України. Проблеми теорії фінансового права в сучасний період: матеріали науково-практичного круглого cтолу. Київський національний університет ім. Тараса Шевченка, 21 листопада 2014. Запоріжжя: КПК. 2014. С. 19-20.

3 Латковська Т.А. Перспективи перетворення Державної фіскальної служби з контролюючого органу на сервісну службу. Правові та інституційні механізми забезпечення розвитку держави та права в умовах євроінтеграиії: матеріали Міжнар. наук.-практ. конф. (20 травня 2016 р., м. Одеса) у 2 т. Т. 2. відп. ред. М.В. Афанасьєва. Одеса: Юридична література, 2016. 712 c. C. $64-66$.

${ }^{4}$ Яковлєв І.П. Форми і методи публічного адміністрування у державній митній справі: дис. ... канд. юрид. наук: 12.00.07 / Одеса, 2016. 224 с. 
provide administrative services to individuals and legal entities, the central executive body is formed as a service ${ }^{5}$.

In 2018, the SFS presented the Strategic Directions for Development up to 2020: IT and infrastructure; services development; effective taxes administration, fees, and customs duties; customs and cross-border cooperation, etc.

Some scholars view the SFS as an institutional organization. When applied to the State Fiscal Service, this means that it is an institutionorganization on several levels:

1) personal - a group, team, a set of people with certain relations;

2) structural;

3) normative - a set of goals, procedures, rules, norms that determine the nature of relations and interactions between members of the organization, as well as the organization as a whole, its individual representatives with the external environment: other organizations and individuals;

4) material and technical - a set of material conditions and means by which the functioning of the organization is created ${ }^{6}$.

The idea of the «dual nature» of the SFS is correct. On the one hand, it is part of the system of central executive bodies, its activities are secondary, by-law, executive-administrative nature, because it is carried out on the basis and implementation of the law; on the other hand, the SFS is a body of state departmental control ${ }^{7}$.

The SFS and its territorial bodies are bodies of revenues and fees. The structure of the SFS consists of staff, territorial bodies, and specialized departments. Also, the SFS and its territorial bodies include tax police units.

The SFS apparatus comprises departments and administrations. The SFS departments include the Department of State Secrets Protection, Technical and Cryptographic Protection of Information, the Department of Personnel Policy and Personnel, the Department of Finance, Accounting and Reporting, the Regulatory and Legal Department, the Department of Administrative Appeals and Judicial Support, etc. 25 of them are known in total. The SFS incorporates Specialized Department for Software

\footnotetext{
5 Про центральні органи виконавчої влади: Закон України від 17.03.2011 № 3166-VI. Biдомості Верховної Ради Украӥни. 2011. № 38. ст. 385.

${ }^{6}$ Бейкун А. Позитивна тенденція розвитку категорії «система» як елемента структурно-функціональної побудови органів державного управління. Право України. 200. №12. C. $51-54$.

7 Лепеха А.В. Інтегральні характеристики Державної фіскальної служби України як інституціональної організації. Публічне адміністрування: теорія та практика. 2016. Вип. 2(16). C. $1-10$.
} 
Development and Maintenance for Revenue and Duties; main operational management; main department of internal security; the main investigative department of financial investigations; procurement management; management of customs statistics.

Territorial bodies of the SFS are located in the regions, their structure consists of the main departments and customs. The specialized departments of the SFS include the Department of Tax and Customs Expertise, the Department of Specialized Training and Cynological Support, and the Information and Reference Department.

The SFS is headed by a Chairman, who is appointed and dismissed by the Cabinet of Ministers of Ukraine upon the presentation of the Prime Minister of Ukraine, submitted on proposals from the Minister of Finance. The maximum number of civil servants and employees of the SFS is approved by the Cabinet of Ministers of Ukraine. Thus, in May 2019, the following capacity of the SFS consented: the staff -508 people, territorial bodies $-10,800$ people, the staff of the State Tax Service - 1,618 people; territorial bodies of the State Traffic Police - 28,252 people.

The purpose of the SFS in accordance with current legislation integrates two points: the execution of public policy and certain proposals submission to the Minister of Finance. As for the first one, it should be noted that the implementation of the state policy of the DSF is aimed at a fairly wide range of areas, namely: the state customs business; the sphere of combating violations in the application of tax and customs legislation; the sphere of control over the production and turnover of alcohol, alcoholic beverages, and tobacco products; administration of the single contribution, as well as combating violations in the application of legislation on the payment of the single contribution; the sphere of control over the timeliness of payments for the single contribution. Implementation of the second paragraph of the tasks of the DSF - submission of certain proposals to the Minister of Finance - is carried out, actually, in the same areas as the first point.

\section{Theoretical and legal analysis of the powers and functions of the State Fiscal Service of Ukraine}

The tasks of the SFS specified in the legislation are achieved with the help of corresponding powers. Those of the State Fiscal Service, are maintained by the Regulations on the State Fiscal Service approved by the resolution of the Cabinet of Ministers of Ukraine on May 21, 2014. The following list is extremely wide and contains more than 90 powers. 
Regarding the legal nature and essence of the SFS powers, many scholars incline to believe that the latter should be classified as discretionary. The term «discretion» is ordinarily used in the appropriate sense. Semantic and etymological analyzes of the «discretion» and «reason» concepts show their similarity. Their meanings in translations are following: discretion, freedom of action, free choice, right of discretion, discretion, prudence, caution, given to own discretion, acting at their own discretion, discretionary ${ }^{8}$.

The existence of discretion in the legal system is due to a number of objective factors, among which is the objective impossibility of regulating the general rules of all individual legal relations; the occurrence of evaluative concepts, dispositive, imperative rules of law, containing relatively specific or alternative sanctions; the presence of open legal lists, gaps in the law, conflicts of law ${ }^{9}$.

The presence of SFS discretionary powers is an obvious fact that cannot be criticized. Some scholars insist on the negative consequences, allowing them to always carry out activities objectively. Of course, the ideal case would be if each relation arising from the activities of the authorities had its own consolidation in regulations, so the existing rules could have an influence. But in practice there will always be situations without detailed legal regulation. That is why the legislator always leaves room for discretion when creating laws and regulations. We consider it necessary for governmental actions in modern conditions because no system of powers can anticipate all possible circumstances that may arise in the future, no matter how detailed legislation is. At the same time, one should be emphasized that if the law establishes one solution, there is no discretion.

Some scholars call discretionary powers the right of a public administration body to make authoritative decisions. They are an element of competence and their use only strengthens the rule of law ${ }^{10}$. Discretionary powers are perceived as those that give an administrative body a certain degree of freedom in making a decision. That is, they allow the to choose one solution that will be the most acceptable among several proposed.

Recommendation of the Committee of Ministers of the Council of Europe № R (80) 2 on the exercise of discretion by administrative authorities, adopted by the Committee of Ministers on March 11th, 1980, considers discretion as

${ }^{8}$ Русско-английский словарь / под общим руководством проф. А.И. Смирницкого. Москва: Рус. яз, 2001. 768 с.

9 Бойко Д.В. Законность и усмотрение в правоприменительной деятельности: дис. ... к.ю.н.: спец. 12.00.01 / Волгоград, 2011. 221 с.

10 Селюков Ф. Ремнев В.И. Социалистическая законность в государственном управлении. Сочиалистическая законность. Москва: Известия, 1980, № 5. С. 78-79. 
powers which the administrative authority may exercise in its disposal, ie, when the body chooses from several legally permissible decisions.

We agree with S.I. Fedchuk, who considers the following to be the discretionary powers of fiscal bodies:

those that give the opportunity at their discretion to evaluate a legal fact and choose one of several forms of response to this fact established in the legal act;

those that allow the office of the fiscal authority, at its discretion, to choose the measure of public legal impact with regard to individuals and legal entities that pay taxes, its type, size, method of implementation;

those that authorize the office of the fiscal authority, at its discretion, to determine the terms and method of administrative decision execution ${ }^{11}$.

While investigating the nature and essence of the SFS powers, it is necessary to mention their direct relation to control, because it is always present in public administration and is one of the main characteristics of the latter.

There are many control powers in the SFS, among them:

- control over the timeliness of taxpayers submissions and the single contribution prescribed by law reporting, the timeliness, accuracy, and completeness of the taxes and fees payment calculation, single contribution, customs, and other payments;

- control over tax and customs legislation compliance;

- control over the postponement, installment, and restructuring of monetary liabilities and / or tax debt;

- control over the persons, observance of foreign economic activity and goods move, control over vehicles across the customs border of Ukraine established by legislation ${ }^{12}$;

- the like.

It is worth noting that control is a form of communication that allows us to determine exactly how the parameters are set by the system. With its help the following administrative tasks are solved: ensuring strict implementation of laws and regulations governing the activities of state bodies and other objects of management; achieving the originality and quality decision making; the increase of executive discipline, responsibility for the

\footnotetext{
${ }^{11}$ Федчук С.I. Проблеми визначеня дискреційних повноважень органів державної фіскальної служби України. Трансформація фіскальної політики України в умовах Євроінтеграції: зб. наук. праць за матеріалами IX науково-практичної інтернет-конференції. Ірпінь, 2017. C. $58-60$.

12 Про державну фіскальну службу: Постанова Кабінету Міністрів України; Положення від 21.05.2014 № 236.
} 
entrusted business; timely taking measures to eliminate the shortcomings identified in the control process; identification of best approaches and their implementation in practice; promoting the correct selection and placement of personnel, timely prevention of their mistakes; implementation of the necessary assistance to subordinate staff and employees ${ }^{13}$.

Control is the power to influence people's behavior or the course of events. The real purpose of it is to ensure the functioning of the bodies in the established directions or processes. Each body has certain goals and powers that it exercises. But in the real situation, there are obstacles that hinder the goals. To stop and prevent this turn of events, we need a mechanism that will help not to lead to unwanted consequences.

First of all, let's take into account that the implementation of all SFS control powers is a manifestation of public financial control. State financial control is a synthesis of financial control types, which is carried out by the relevant subjects of state financial control to achieve the goals and interests of the state. It consists in establishing the actual state of affairs and compliance with current legislation by control over legality, financial discipline and rationality in the formation, distribution, ownership, use and alienation of the subject of control, ie state-owned assets and the use of funds remain with the subject of financial relations and are connected to the benefits provided for budget payments, state extra-budgetary funds and loans received under state guarantees ${ }^{14}$.

According to the current legislation of Ukraine, the state financial control is provided by the state financial control body through the state financial audit, inspection, procurement verification, and procurement monitoring ${ }^{15}$. The implementation of state financial control through the exercise of SFS powers is different. Therefore, the powers themselves can be divided according to this basis of classification.

First of all, we are talking about tax control. As a type of state financial control, it is primarily centered around the constant detection and removal of taxes and fees arrears in the budget system, as well as preventing violations of tax legislation ${ }^{16}$.

\footnotetext{
${ }^{13}$ Больбіт Ю.Л. Державна фіскальна служба України як об’єкт державного контролю. Науковий вісник Ужгородського національного університету. Серія: Право. 2014. Вип. 29(2.3). C. 94-97.

14 Хмельков А.В. Державний фінансовий контроль: навч. посіб. Харків: ХНУ імені В.Н. Каразіна, 2013. 549 с.

15 Про основні засади здійснення державного фінансового контролю в Україні: Закон України від 26.01.1993 № 2939-ХІІ. Відомості Верховної Ради Украӥни. 1993. № 13. ст. 110.

${ }^{16}$ Ногина О.А. Налоговый контроль: вопросы теории. Санкт-Петербург: Питер, 2002. 150 с..
} 
According to the legislation of Ukraine, tax control is a system of measures taken by controlling bodies and coordinated by the central executive body that ensures the formation and implementation of public financial policy, to control the correctness of accrual, completeness, and timeliness of taxes and fees, regulation of cash circulation, settlement and cash transactions patenting, licensing, and other legislations, the control of which is entrusted to controlling bodies ${ }^{17}$.

The powers of the SFS in the field of tax control include control over compliance with tax and customs legislation, legislation on transfer pricing, legislation on the administration of the single contribution and others; control over deferral, installment and restructuring of monetary obligations and/or tax debt, as well as arrears of payment of a single contribution; initiating the application of bankruptcy proceedings to taxpayers and single contributors; controls the timeliness of submission by taxpayers and the single contribution of statutory reporting, timeliness, reliability, completeness of accrual and payment of taxes and fees, single contribution, customs, and other payments, etc.

The next type of state financial control, which is carried out with SFS help are customs. It performs all important functions to ensure financial and customs security. According to the Customs Code of Ukraine, customs control is a set of measures taken to ensure compliance with the Code, laws and other regulations on customs matters, international treaties of Ukraine concluded in the manner prescribed by law ${ }^{18}$.

Among the SFS powers exercised in the field of customs there are the next:

- control over compliance with customs legislation;

- over the observance of the procedure established by the legislation for the movement of goods and vehicles across Ukrainian customs border, by the subjects of foreign economic activity;

- control over the correctness of goods value;

- determining the customs value of goods in accordance with the law, as well as the correctness of determining the country of origin and classification of goods moving across the customs border of Ukraine according to the Ukrainian Classification of Goods for Foreign Economic Activity (UCGFEA);

- ensuring the application of customs regimes, customs control and customs clearance of goods placed in the relevant customs regimes; over

17 Податковий кодекс України: Кодекс України від 02.12.2010 № 2755-VI. Відомості Bepховної Ради України. 2011. № 13-14, № 15-16, № 17, ст. 112.

18 Митний кодекс України: Кодекс України від 13.03.2012 № 4495-VI. Відомості Верховної Ради Украӥни. 2012. № 44-45, № 46-47, № 48, ст. 552. 
the observance of the legislation on the state control by the subjects of foreign economic activity;

- over the international transfers of military and dual-use goods, within the powers provided by law;

- application and control of procedures for the use of guarantees to ensure the payment of customs duties;

- control over the completeness and correctness of customs formalities, etc ${ }^{19}$.

The next area of SFS powers execution is budget control, i.e. the receipt of taxes and fees, customs and other payments, and state trust funds. The fact that the SFS is one of the leading state bodies that carry out its activities to fill the state budget also testifies to the significant contribution to budget control. At the same time, it should be known that this is due to the two areas of public financial control covered above - customs and tax. The following powers are used in the sphere of budgetary control to implement the tasks assigned to the SFS: control over the observance of the procedure for acceptance and accounting of taxes and fees from taxpayers, timeliness, and completeness of the transfer of these amounts to the budget, by executive councils of villages; control over the legality of budget reimbursement of value-added tax, etc.

Analysis of paragraph 4 of the Regulation on the State Fiscal Service of Ukraine, allows us to conclude that they are not limited to the scope of control. Given this, we consider it appropriate to identify other types of powers, depending on the areas of their implementation and tasks to achieve which is their implementation.

Thus, the SFS directs a wide range of functions to assess the current state of affairs in the areas of state tax policy, state policy in the field of state customs, state policy on the administration of a single contribution to compulsory state social insurance, state policy in the fight against crime, application of tax, customs legislation, as well as legislation on the payment of a single contribution.

That is why it is possible to separate the expert-analytical powers of the SFS into the groups. These include: generalized practice of application of legislation on issues within the competence of the SFS; development of proposals for improving legislative acts, acts of the President of Ukraine and the Cabinet of Ministers of Ukraine, normative legal acts of ministries; development of draft laws of Ukraine, acts of the President of Ukraine, the Cabinet of Ministers of Ukraine, orders of the Ministry of Finance on issues

19 Про державну фіскальну службу: Постанова Кабінету Міністрів України; Положення від 21.05.2014 № 236 . 
related to the scope of the SFS; development of forms of tax declarations (calculations), reports and other documents; preparation of proposals for the forecast of budget revenues and single contribution revenues, taking into account the forecast of macroeconomic indicators and trends in the world economy; conducts research and expert activities in the tax and customs spheres; risk analysis and management in order to determine the forms and scope of customs and tax control; interaction and exchange of information with public authorities, foreign state bodies, international organizations; analysis and generalization of information on violations of the customs legislation violation, based on the results of measures aimed at preventing violations; submission to the Ministry of Finance on the basis of macroeconomic indicators and trends in the world economy of a proposal to determine the forecast (indicative) indicators of state budget revenues for the draft law on the State Budget of Ukraine for the year, etc.

The next group is the powers exercised in the field of offenses. These include:

- dentifying the causes and conditions that led to the commission of criminal and other offenses in taxation, customs, and budgetary spheres;

- taking measures to eliminate them;

- receiving and registering applications, notifications and other information on criminal and other offenses in taxation and the budget, making decisions on them provided by law;

- detection of criminal and other offenses in taxation, customs, and budgetary spheres, as well as establishing the location of taxpayers, interviewing their founders, officials;

- taking measures to protect intellectual property rights in the process of foreign economic activity, preventing the movement of counterfeit goods across the Ukrainian customs borders; prevention and counteraction to smuggling and violation of customs rules in the territory of Ukraine, etc.

Another group of powers of the SFS that can be distinguished is the authorizing. These include the application of sanctions for late submission of reports established by law, the control of which is entrusted to the SFS; carrying out debt collection from business entities on loans and borrowings raised by the state or under state guarantees; repayment of the tax debt of taxpayers, as well as recovery of timely accrued and/or unpaid amounts of the single contribution from the payers; application of administrative seizure (seizure) of taxpayers' property and/or suspension of expenditure transactions on their bank accounts, financial sanctions against single contribution payers. 
The functions of the State Fiscal Service are not clearly established by the legislator. In scientific doctrine, the relationship between the concepts of «task» and «function» often leads to the conclusion that they are identical. Under the task, it is expedient to understand the process of execution of everything, the realization of which is provided by him, or should be provided. While the function is the relationship between tasks and competence as a legal ${ }^{20}$. This approach does not seem to fully characterize the nature and content of such categories as «function» and «authority». We agree with the opinion that the ratio of such concepts as a single whole or the same type of socio-legal phenomenon somewhat blurs the boundaries of their perception in the practical aspect of the activities of individual public authorities in different areas ${ }^{21}$.

Analyzing the tasks of the SFS and its powers regulated by law, we can identify its functions. If we take the approach that the function is the direction of activity, and the direction of activity, in turn, is formed by a set of certain powers as a basis, we can determine that the SFS has such functions as control, expert-analytical, preventive, law-enforcement.

One that is worth noting is the function of fiscal administration, which can be safely attributed to the activities of the SFS. Fiscal administration is currently a little-studied concept among scholars and an uncertain legislator. Some refer to it as tax administration, defining that fiscal administration itself as the component. We will define tax administration as the administrative activity of the state in the field of substantiation and tax policy development, organization of the taxation process and ensuring timely and full payment of taxes and fees by taxpayers. Tax administration can be divided into the following branches: fiscal administration and administration of tax liabilities ${ }^{22}$.

Other scholars, on the other hand, believe that fiscal administration is a broader concept than tax administration, and includes the latter. Fiscal administration, in addition to tax administration, includes administration of non-tax revenues, administration of budget expenditures, administration of public debt ${ }^{23}$.

\footnotetext{
${ }^{20}$ Драго Р. Административная наука. / пер. с франц. Л. Энтина под ред. и послесл. Б.М. Лазарева. Москва: Прогресс, 1982. 245 с.

21 Чорна А.М. До проблеми співвідношення понять «завдання» та «функції» Державної фіскальної служби України. Право і Безпека. 2015. № 2. С. 75-80.

22 Савчук В.А. Теоретичні засади організації адміністрування податків. Ефективна економіка. 2013. № 3.

${ }^{23}$ Проскура К.П. Податкове адміністрування в Україні в посткризовий період: ефективність та напрями модернізації. Київ: ТОВ «Емкон», 2014. 376 с.
} 
The most important and defining component of fiscal administration is tax administration, the dominant due to the share of tax revenues in budget revenues and the uniform principles of accounting, calculation, payment (collection) of tax payments, as well as the responsibility of taxpayers ${ }^{24}$. Thus, in the scientific and legal doctrine two diametrically opposite directions of understanding of fiscal administration were formed.

We consider the first approach incorrect. To understand the content of fiscal administration, it is first necessary to determine its etymology. The term «fiscal» (from the Latin Fiscus, literally - basket) comes from the French «Fiscus»-purse, treasury. In ancient Rome, this was the name of the military treasury, which accumulated all the funds needed to maintain the army. Since the XVI century. this term was used to mean the state treasury, treasury. The concept of «fisc» and its derivatives entered the socio-political, and later scientific use in the polysemantic sense of the set of state revenues, budget funds, as well as the state itself in understanding its property and financial rights and obligations to individuals and legal entities ${ }^{25}$.

It can be concluded that fiscal administration is not limited to activities in one area. Its implementation is important not only for taxes but also for all financial resources owned by the state. In general, fiscal administration includes several areas: tax and revenue management; distribution of budget resources; government borrowing and debt management; Accounting, and Audit. In the context of the study of the concept of «fiscal», it seems appropriate to pay attention to the difference between the concepts of «fiscal» and «tax», given that the first of them has a broader semantic meaning. In most modern dictionaries, the essence of the concept of «fisc» is associated with financial resources available to the state or, in other words, the state treasury - a storehouse of money, jewelry, and other material values ${ }^{26}$.

Scientist Andrushchenko V.L considers fiscal administration in three definitions - as a science, as public policy, and as a field of knowledge. Examining fiscal administration as a state policy, he determines that fiscal administration is a state policy in the sense of government actions and management structures, through which available financial resources are distributed in certain proportions by the tax mechanism between private

\footnotetext{
24 Загородній А.Г. Фінансово-економічний словник. Київ: Знання, 2007. 1072 с.

25 Андрущенко В.Л. Фіскальне адміністрування як наука і мистецтво. Фінанси Украӥни. 2003. № 6. С. 27-35.

${ }^{26}$ Славкова А.А. Адміністрування податків і сервіс платників: відмінності та взаємозв'язок. Економічний форум. 2016. № 1. С. 328-335.
} 
and public sectors, between the state and the population. The government implements its functions at the expense of taxes ${ }^{27}$.

Fiscal administration is considered as public administration - the tax system as a whole and structural elements - individual taxes on their legislative implementation and design, planning and operational management, tax control over compliance with the law by taxpayers ${ }^{28}$.

Analyzing the definition of fiscal administration, we can safely say that the State Fiscal Service of Ukraine, among other functions mentioned above, performs the function of fiscal administration. After all, its main tasks are to implement state policy in the field of control over revenues to the state budget, on the administration of a single contribution, as well as combating offenses in the application of tax legislation. To perform this function, the SFS has a wide range of powers, which was discussed above.

The function of the fiscal administration of the State Fiscal Service is to exercise powers aimed at organizing, coordinating and forecasting processes aimed at the efficient use of public funds.

\section{CONCLUSIONS}

The State Fiscal Service of Ukraine is a body of public administration, which carries out its activities with the help of its territorial bodies in specialized departments. It is publicly administered in the field of finance. With the help of the powers of the State Fiscal Service of Ukraine, management is carried out. It ensures the implementation of state policy in the field of finance. The activity of the State Fiscal Service of Ukraine is operated by the relevant regulation approved by the resolution of the Cabinet of Ministers of Ukraine, which clearly specifies its tasks and powers. With regard to the latter, it should be noted that they have a sign of discretion, i.e. the ability to assess the legal fact at their own discretion and choose one of several forms of response established in the legal act. The powers of the fiscal service can be divided according to the scope of their implementation. First of all, it is the control powers exercised in the field of state financial control - tax, customs, budget. Their number is perhaps the largest among other powers of the fiscal service, enshrined in law. Another group consists of expert-analytical powers. The following is the prevention of offenses. Another group is the powers that enable the State Fiscal Service to apply sanctions.

\footnotetext{
27 Андрущенко В.Л. Фіскальне адміністрування як наука і мистецтво. Фінанси Украӥни. 2003. № 6. С. 27-35.

${ }^{28}$ Новосад Л.Я. Фіскальне адміністрування в Україні: проблеми теорії та практики. Cвim фінансів. 2005. Вип. 1. С. 65-70.
} 
The State Fiscal Service of Ukraine operates such functions as control, expert-analytical, preventive, law-renewing, and the function of fiscal administration.

\section{SUMMARY}

The article examines the scientific and legal characteristics of the State Fiscal Service of Ukraine and the theoretical and legal analysis of its functions and powers. It is proved that the State Fiscal Service is a body of public administration, which is carried out in the field of finance. The normative-legal acts regulating the activity of the State Fiscal Service are studied and the basic scientific concepts of its activity are considered. It is also proved that the powers of the SFS have a sign of discretion. It is substantiated that among the powers of the SFS can be distinguished control, expert-analytical, preventive, renewal. In turn, control powers can be classified depending on the scope of control: powers of tax control, budget, and customs control. The functions of the SFS include control, expertanalytical, prognostic, preventive and the function of fiscal administration.

\section{REFERENCES}

1. Про державну фіскальну службу: Постанова Кабінету Міністрів України; Положення від 21.05.2014. № 236.

2. Гнатовська А.І. Правові засади створення державної фіскальної служби України. Проблеми теорії фінансового права в сучасний період: матеріали науково-практичного круглого столу. Київський національний університет ім. Тараса Шевченка, 21 листопада 2014. Запоріжжя : КПК. 2014. C. 19-20.

3. Латковська Т.А. Перспективи перетворення Державної фіскальної служби з контролюючого органу на сервісну службу. Правові та інституційні механізми забезпечення розвитку держави та права в умовах євроінтеграції : матеріали Міжнар. наук.-практ. конф. (20 травня 2016 р., м. Одеса) у 2 т. Т. 2. відп. ред. М.В. Афанасьєва. Одеса : Юридична література, 2016. 712 с. (С. 64-66).

4. Яковлєв І.П. Форми i методи публічного адміністрування у державній митній справі : дис. ... канд. юрид. наук : 12.00.07 / Одеса, 2016. 224 c.

5. Про центральні органи виконавчої влади: Закон України від 17.03.2011 № 3166-VI. Відомості Верховної Ради України. 2011. № 38. ст.385.

6. Бейкун А. Позитивна тенденція розвитку категорії «система» як елемента структурно-функціональної побудови органів державного управління. Право України. 200. N 12. С. 51-54. 
7. Лепеха А.В. Інтегральні характеристики Державної фіскальної служби України як інституціональної організації. Публічне адміністрування: теорія та практика. 2016. Вип. 2(16). С. 1-10.

8. Русско-английский словарь / под общим руководством проф. А.И. Смирницкого. Москва : Рус. яз, 2001. 768 с.

9. Бойко Д.В. Законность и усмотрение в правоприменительной деятельности: дис. ... к. ю. н.: спец. 12.00.01 / Волгоград, 2011. 221 с.

10. Селюков Ф. Ремнев В.И. Социалистическая законность в государственном управлении. Социалистическая законность. Москва : Известия, 1980, № 5. С. 78-79

11. Федчук C.I. Проблеми визначення дискреційних повноважень органів державної фіскальної служби України. Трансформація фіскальної політики України в умовах Євроінтеграції : зб. наук. праць за матеріалами IX науково-практичної інтернетконференції. Ірпінь, 2017. С. 58-60.

12. Больбіт Ю.Л. Державна фіскальна служба України як об'єкт державного контролю. Науковий вісник Ужгородського наџіонального університету. Серія : Право. 2014. Вип. 29(2.3). С. 94-97

13. Хмельков А.В. Державний фінансовий контроль : навч. посіб. Харків : ХНУ імені В.Н. Каразіна, 2013. 549 с.

14. Про основні засади здійснення державного фінансового контролю в Україні: Закон України від 26.01.1993 № 2939-XII. Вiдомості Верховної Ради України. 1993. № 13. ст. 110.

15. Ногина О.А. Налоговый контроль: вопросы теории. СанктПетербург : Питер, 2002. 150 с.

16. Податковий кодекс України : Кодекс України від 02.12.2010 № 2755-VI. Відомості Верховної Ради України. 2011. № 13-14, № 15-16, № 17 , ст. 112

17. Митний кодекс України : Кодекс України від 13.03.2012 № 4495-VI. Відомості Верховної Ради України. 2012. № 44-45, № 46-47, № 48, ст. 552.

18. Драго Р. Административная наука. / пер. с франц. Л. Энтина под ред. и послесл. Б.М. Лазарева. Москва : Прогресс, 1982. 245 с.

19. Чорна А.М. До проблеми співвідношення понять «завдання» та «функції» Державної фіскальної служби України. Право $і$ Безпека. 2015. № 2. С. 75-80.

20. Савчук В.А. Теоретичні засади організації адміністрування податків. Ефективна економіка. 2013. № 3.

21. Проскура К.П. Податкове адміністрування в Україні в посткризовий період: ефективність та напрями модернізації. Київ : ТОВ «Емкон», 2014. $376 \mathrm{c}$.

22. Загородній А.Г. Фінансово-економічний словник. Київ : Знання, 2007. $1072 \mathrm{c}$ 
23. Андрущенко В.Л. Фіскальне адміністрування як наука і мистецтво. Фінанси Украӥни. 2003. № 6. С. 27-35.

24. Славкова А.А. Адміністрування податків і сервіс платників: відмінності та взаємозв'язок. Економічний форум. 2016. № 1. С. 328-335.

25. Новосад Л.Я. Фіскальне адміністрування в Україні: проблеми теорії та практики. Світ фінансів. 2005. Вип. 1. С. 65-70.

\section{Information about author: Marushak A. V.,}

Ph.D. in Law, Associate Professor, Senior Lecturer at the Department of Constitutional, Administrative and Financial Law Chernivtsi Law Institute of the National University "Odessa Law Academy" 7, Skovorody str., Chernivtsi, 58000, Ukraine ORCID ID: 0000-0002-4611-4906 